\title{
Quenching and Partitioning Heat Treatment in Ductile Cast Irons
}

\author{
Anderson José Saretta Tomaz da Silva*, Hélio Goldenstein ${ }^{b}$, \\ Wilson Luiz Guesser ${ }^{c}$, Marcos Flávio de Campos ${ }^{d}$ \\ ${ }^{a}$ Tupy S.A., Manoel da Nóbrega, 424, CEP 09380-120, Mauá, SP, Brazil \\ ${ }^{b}$ Metallurgical Engineering Department, Universidade de São Paulo - USP, Av. Prof. Mello Morais, \\ 2463, CEP 05508-030, São Paulo, SP, Brazil \\ ${ }^{c}$ Center of Thecnological Sciences, Universidade do Estado de Santa Catarina - UDESC, \\ Campus Universitário Prof. Avelino Marcante, Rua Paulo Malschitzki, s/n, \\ CEP 89219-710, Joinville, SC, Brazil \\ ${ }^{d}$ Universidade Federal Fluminense - UFF, Av. dos Trabalhadores, 420, Vila Santa Cecilia, \\ CEP 27255-125, Volta Redonda, RJ, Brazil
}

Received: July 24, 2013; Revised: October 2, 2014

\begin{abstract}
A commercial ductile iron alloy was submitted to a quenching and partitioning heat treatment. Samples were austenitized at $900{ }^{\circ} \mathrm{C}$ for two hours, quenched at $160{ }^{\circ} \mathrm{C}$ and kept at this temperature for 2 minutes and finally were re-heated at temperatures between 300 and $450{ }^{\circ} \mathrm{C}$ during time intervals between 2 and 180 minutes. The microstructural evaluation was performed with SEM and X-ray diffraction and the mechanical properties were measured using tensile strength and Charpy tests. In general, the quenching and partitioning treatment is viable to achieving expressive fractions of retained austenite in ductile cast irons. Generally, higher partitioning temperatures produce a higher fraction of retained austenite after shorter times. This behavior can be explained by the increase on diffusion rate of carbon at higher temperatures. For all tested conditions it was possible to see a well-defined process window and the combination of mechanical properties is very similar to the austempered ductile irons.
\end{abstract}

Keywords: quenching, partitioning, austenite

\section{Introduction}

Recent developments for the search of new grades of steels containing small fractions of retained austenite are introducing a new concept of heat treatment, identified as quenching and partition. This cycle of heat treatment is an alternative route for obtaining multi-phase steel, where the volumetric fraction of retained austenite is controlled by the phenomenon of carbon partition from the martensite until the austenite is stabilized ${ }^{1}$.

The concept of quenching and partition involves partial transformation of the austenite to martensite, through a quenching at temperatures between Ms (martensite start temperature) and Mf (martensite final temperature), followed by a thermal partitioning treatment, which allows the carbon to diffuse from the supersaturated martensite to the non-transformed austenite. The increased carbon in the austenite lowers its Ms temperature promoting the stabilization of this phase ${ }^{2}$.

In the conventional quenching process, the carbon partitioned between martensite and austenite is usually ignored because the supersaturation of the martensite is eliminated by competitive processes, and among them the most common is the carbides precipitation during tempering. The stabilization of austenite using the carbon from martensite only will be possible with the existence of non-transformed austenite after quenching and if the carbide

*e-mail: andersonts@tupy.com.br precipitation is suppressed or retarded by the presence of silicon or aluminum alloy additions ${ }^{1}$. If these conditions are fulfilled, it is possible to obtain austenite enriched with carbon, which will be stable at room temperature.

Studies conducted by several researchers ${ }^{3,4}$ proved the possibility of achieving fractions of retained austenite through quenching and partitioning heat treatments in silicon containing steels. In these studies, it was possible to observe the dependence between the fractions of retained austenite (as well as its final carbon content) and the heat treatment conditions. These studies demonstrate that, with increased partitioning temperature, the kinetic of the reactions is accelerated, obtaining higher fractions of retained austenite after a shorter period of time. After a giving moment, this austenite fraction starts decreasing, indicating the beginning of transformation to other type of products (carbide containing phases). Transmission electron microscopy dark field images confirm that the final structure is composed of thin flakes of austenite between martensite plaques.

The austempering process in ductile irons uses the stasis of the bainitic reaction, followed by a similar carbon thermal partition phenomenon for obtaining austenite stable at the room temperature. The structure of ADI (austempered ductile iron) is composed of needles of bainitic ferrite in a retained austenite matrix. The austenite with low carbon content is firstly decomposed forming sheaves of ferrite 
needles, nucleated at austenite/graphite interfaces and on austenitic grain boundaries with the growth stasis of the ferrite needles. Then the carbon is partitioned to the remaining austenite, which will reach the equilibrium due to the oversaturation of the carbon originated from the areas transformed into ferrite ${ }^{5}$.

Recent works evidenced that the quenching and partition heat treatment cycle is a feasible route for the achievement of combinations of high tensile strength with reasonable tenacity or toughness, using relatively simple $\mathrm{e}^{6,7,8}$ commercial steel. The suppression of carbides improves the toughness of steels and the retained austenite will protect the bainite or the martensitic ferrite from the detrimental effects in mechanical properties caused by carbides dispersion. The high carbon concentration in the austenite will work as chemical stabilizer for this phase, preventing future decomposition. This concept is reverse to the one used on conventional quenching and tempering processes, where the volumetric fraction of remaining austenite is decomposed to ferrite plus carbides, stabilizing the microstructure ${ }^{6}$. The retention of fractions of austenite (face-centered cubic) promotes elevated ductility during subsequent deformation processes. Thus, the austenite phase does not cleave, acting as a damper for brittle cracks propagation, increasing the material toughness ${ }^{7}$.

The main objective of this work is obtaining knowledge about the behavior of nodular cast irons heat treated in quenching and partitioning cycle. It is expected a better understanding of the evolution of the microstructure during the heat treatment, in order to identify the existence of a process window, which leads to optimal mechanical properties. The major contribution expected by applying this route in ductile iron is the development of a class of heat-treated nodular cast iron, which can be a technological alternative in applications where the austempered ductile iron are consolidated materials.

\section{Experimental Methods}

The present study aimed to evaluate the influence of different conditions on quenching and partition in the microstructure and mechanical properties of a commercial ductile iron alloy, used in components of the automotive industry. The chemical composition of the alloy used in this study can be seen in Table 1 .

The microstructure observed in the as-cast condition is perlite and ferrite. The observed nodularity was $95 \%$. It is well known that the properties of the ductile cast irons are strongly dependent on the distribution, morphology and quantity of the spheroidal graphite. Increasing the nodularity allows the optimization of the mechanical properties ${ }^{9}$. The determined nodule counting was 122 nodules $/ \mathrm{mm} 2$. A high nodule count is essential to distribute the segregation of chemical elements during solidification, which is one of the most important characteristics of cast irons ${ }^{9}$. The minimum nodule counting recommended for ductile irons subjected to austempering treatment is 100 nodules $/ \mathrm{mm} 2$. A small nodule counting will result on a coarse structure with more space between graphite nodules, causing areas prone to segregation ${ }^{9}$. The samples were taken from Y-blocks $25 \mathrm{~mm}$ thick, $40 \mathrm{~mm}$ wide and $135 \mathrm{~mm}$ high. The austenitization was performed at $900{ }^{\circ} \mathrm{C}$, during two hours. These parameters are typically used in the austenitization of ductile irons in austempering process. The Ms temperature was estimated with empirical equations from the literature, which make use of the chemical composition of the material ${ }^{10}$. Using a thermodynamic simulation software (Thermocalc) it was possible to calculate the chemical composition of austenite at austenitization temperature $\left(900^{\circ} \mathrm{C}\right)$, as seen in Table 2 .

Applying Andrews's linear equation ${ }^{10}$ (Equation 1) it was possible to make an estimative of the Ms temperature, which was found to be $184.62^{\circ} \mathrm{C}$. Under these circumstances the selected temperature for quenching were $160^{\circ} \mathrm{C}$. According to Koistinen and Marburger equation ${ }^{11}$ (Equation 2 , where $\mathrm{V} \alpha=$ percentage of austenite transformed in martensite, $\beta=0,011$ and $\mathrm{Tq}=$ temperature of quenching) this is sufficient for transforming $31 \%$ of austenite into martensite during the quenching.

$\mathrm{M}_{\mathrm{s}}\left({ }^{\circ} \mathrm{C}\right)=539-423 \mathrm{C}-30,4 \mathrm{Mn}-$

$12,1 \mathrm{Cr}-7,5 \mathrm{Mo}-7,5 \mathrm{Si}$

$1-\mathrm{V} \alpha=\exp \{\beta(\mathrm{Ms}-\mathrm{Tq})\}$

The austenitization was performed in muffle oven with temperature range varying from 50 to $1100{ }^{\circ} \mathrm{C}$. The temperature control was carried out through K-type thermocouple with measurement range between -200 and $1300{ }^{\circ} \mathrm{C}$ and average variation of $0.75 \%$ compared to the measured value.

The quenching was performed in oil Thermisol RT SS with cooling rate between 400 and $100{ }^{\circ} \mathrm{C} / \mathrm{s}$. The holding time for quenching temperature was 2 minutes. The partitioning step was also conducted in muffle oven, using controls similar to those used in the austenitization step. The temperatures used on the partition process after quenching were defined with basis on other studies available in literature ${ }^{3,8,12}$. The temperatures used on the partitioning step were 300,375 and $450{ }^{\circ} \mathrm{C}$. The holding time in the

Table 1. Chemical composition of alloy used in the present study (wt \%).

\begin{tabular}{ccccccccccc}
\hline Element & $\mathbf{C}$ & $\mathbf{S i}$ & $\mathbf{M n}$ & $\mathbf{P}$ & $\mathbf{S}$ & $\mathbf{C r}$ & $\mathbf{C u}$ & $\mathbf{M g}$ & $\mathbf{M o}$ & $\mathbf{N i}$ \\
\hline Alloy \#1 & 3.49 & 2.22 & 0.24 & 0.04 & 0.01 & 0.03 & 0.49 & 0.043 & - & 0.01 \\
\hline
\end{tabular}

Table 2. Chemical composition (wt \%) of austenite at $900{ }^{\circ} \mathrm{C}$, estimated by Thermocalc.

\begin{tabular}{cccccccc}
\hline Element & $\mathbf{C}$ & $\mathbf{S i}$ & $\mathbf{M n}$ & $\mathbf{C r}$ & $\mathbf{C u}$ & $\mathbf{N i}$ \\
\hline Alloy\#1 & 0.78 & 2.28 & 0.229 & 0.0308 & 0.503 & 0.0102 \\
\hline
\end{tabular}


partitioning temperatures were $2,5,10,20,30,60,120$ and 180 minutes.

The metallographic preparation followed conventional methods, first applying regular sandpaper (up to \#1200 coarse), followed by polishing the sample with 3 and $1 \mathrm{~mm}$ diamond paste. Chemical etching of polished sections was performed using 2\% Nital reagent. The Sanning Electron Microscope (SEM) images were obtained in a Phillips XL30 microscopy using secondary and backscattered electrons. X-ray diffraction techniques were used for the determination of the volumetric fraction of retained austenite in the samples. A Shimadzu model 6000 diffractometer was used. The scanning was made in an angular interval of $2 \theta=30-110^{\circ}$, step size of $0,02^{\circ}$, time per step of six seconds. It was used radiation of $\mathrm{Co}-\mathrm{K} \alpha$, with graphite monocromator. The proportions between the retained austenite and ferrite were obtained through analysis with Rietveld method. The software used was TOPAS ACADEMIC 4.1.

The Charpy test was used for evaluating mechanical properties, with samples without notch. The impact tests were carried out in a Wolpert machine-model PW 20/30K. A $30 \mathrm{KPM}$ hammer was used, with speed of $5-7 \mathrm{~m} / \mathrm{s}$. The tensile strength samples used were removed from Y-blocks. The tests were conducted in an EMIC universal machine, model DL 20000 with loading capacity between 200 and $20000 \mathrm{Kgf}$ and loading speed from 0.01 to $500 \mathrm{~mm} / \mathrm{min}$.

\section{Results}

\subsection{Scanning Electron Microscopy (SEM)}

The analysis of the microstructure with SEM shown that the microstructure of almost all treated samples had pronounced differences between the intercellular regions and the areas around graphite nodules, as can be seen in Figure 1. Around the nodules, it was observed the presence of ausferrite (bainitic ferrite + retained austenite), which is a common microstructure in austempered ductile irons. On the other hand, the intercellular area was composed predominantly of fresh high carbon martensite, probably formed by the transformation of unstable austenite during final cooling. These heterogeneities points out a pronounced segregation of elements during solidification, a common characteristic of cast irons.

Chemical elements such as manganese, molybdenum and chromium commonly segregate towards eutectic cells boundaries. In practice, when comparing areas around the nodules and intercellular areas, it is like two different alloys with different compositions coexist. Therefore, the kinetics of transformations resulting from heat treatment will have behave differently on both areas ${ }^{9}$. This phenomenon will allow that in the same heat treatment it is possible the precipitation of carbides from high carbon austenite in areas close to the graphite nodules, whereas in the intercellular areas, there is still austenite with low carbon content, which will be transformed to martensite during final cooling. The differences in chemical composition will not have here significantly effect, due to the relatively short austenitization times applied in this study. Therefore different percentages of carbon and substitutional elements will be present, in metastable equilibrium with graphite, in intercellular areas and around the nodule at the end of the austenitization process. Consequently, the Ms temperature and the amount of martensite produced during quenching will be different in these areas.

An estimate of these differences in local chemical composition can be obtained using thermodynamic calculation with the Thermocalc software. These approximate chemical compositions can be applied to empirical equations (such as Andrews and Koistinen Marburger) aiming to estimate the temperatures where the martensitic transformation will start at each region.

Using the EDS technique it was possible to carry out semi-quantitative measurements of the chemical compositions close to the nodule and in the intercellular area, in a sample solubilized and quickly quenched in oil. The chemical composition of the austenite at $900{ }^{\circ} \mathrm{C}$ (estimated by Thermocalc) on the intercellular areas and around the graphite nodules can be seen in Table 3 .

Using Andrews's linear equation, it was possible to obtain the Ms temperature near of the nodule as $196^{\circ} \mathrm{C}$ and $153.5^{\circ} \mathrm{C}$ in the intercellular area. These Ms temperatures were used in the Koistinen - Marburger equation to
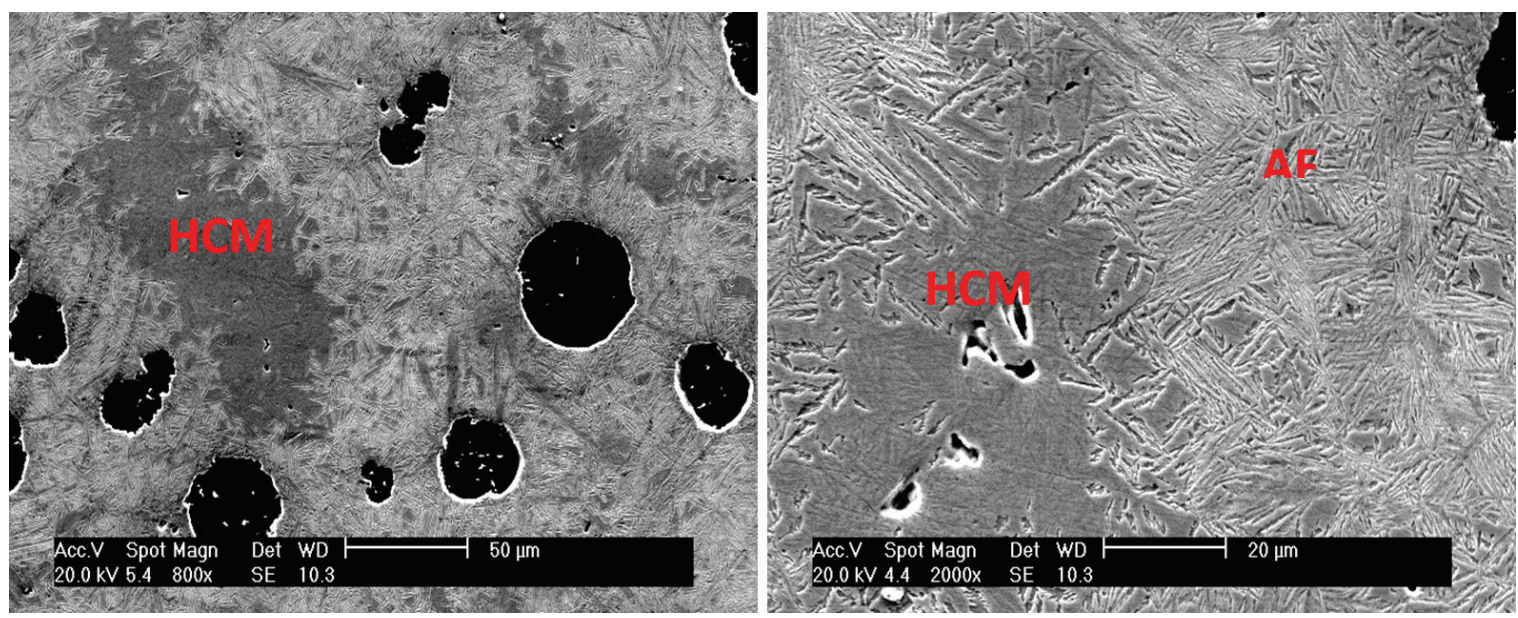

Figure 1. Microstructure of the samples partitioned at $300{ }^{\circ} \mathrm{C}$ during 2 minutes, showing the differences of microstructures around the nodules $(\mathrm{AF}=$ ausferrite $)$ and around the eutectic cells $(\mathrm{HCM}=$ high carbon martensite $)$. 
provide an estimate of the fraction of the matrix, which is transformed in martensite in each area. Through this calculation it was possible to observe that the chosen temperature was able to transforming $48 \%$ of austenite in martensite around the nodules $\left(\mathrm{Ms}=196{ }^{\circ} \mathrm{C}\right)$ and $0 \%$ in the intercellular areas $\left(\mathrm{Ms}=153.5^{\circ} \mathrm{C}\right)$. This result explains the existence of martensite obtained through quenching in areas close to nodules (higher Ms) and the predominance of martensite formed during the cooling to room temperature in the intercellular areas, where it was not possible generating martensite in the quenching because the local Ms temperature is lower than the temperature used to quenching the samples.

The microstructure around the nodules is composed of low carbon martensite formed during quenching (the carbon was partitioned during the isothermal heat treatment) plus ausferrite, the later being the typical microstructure of austempered ductile cast irons (bainitic ferrite free of carbides + retained austenite), formed during isothermal treatment at $300{ }^{\circ} \mathrm{C}$. On the other hand, the microstructure in the intercellular areas is composed of high carbon martensite formed during final cooling to the room temperature. Due to lower Ms values, these intercellular areas remained austenitic during quenching, and there was not enough time for diffusing the carbon and reaching the stability of this phase. During the final cooling the unstable austenite is transformed into martensite.

Table 3. Chemical composition (wt \%) of the austenite at $900{ }^{\circ} \mathrm{C}$ estimated by Thermocalc.

\begin{tabular}{lccccc}
\hline \multicolumn{1}{c}{ Location } & $\mathbf{F e}$ & $\mathbf{C u}$ & $\mathbf{C}$ & $\mathbf{S i}$ & $\mathbf{M n}$ \\
\hline Around graphite & $9.34 \mathrm{E}+01$ & 1.025 & 0.688 & 3.687 & 0.771 \\
Intercellular & $9.36 \mathrm{E}+01$ & 1.024 & 0.783 & 3.024 & 1.045 \\
\hline
\end{tabular}

Micrographs presented in Figure 2 show the high carbon martensite (HCM) formed in intercellular areas during final cooling to room temperature, and also the ausferritic structure (AF) formed predominantly around graphite nodules as well as areas composed of partitioned martensite, formed during quenching (PM).

The carbon of the plate martensite observed around the nodule (formed during quenching) diffused to the remaining austenite, eliminating the martensite super saturation. In this way, this is plate (morphologically) martensite but with low carbon content and body centered cubic structure, similar to ferrite. The two martensitic areas presented in Figure 3 have distinct morphology and mechanical properties due to the different carbon content in solution. The low carbon content of the martensite around the graphite nodules allows this phase presenting lower hardness. On the other hand, the martensite in the intercellular areas has higher carbon content and, therefore, this phase is potentially brittle due to its high hardness, high tetragonality and high level of residual stresses.

Summarizing, the final microstructure obtained after quenching and partitioning in ductile cast irons is composed of graphite nodules formed during solidification and a mixture of ausferrite (bainitic ferrite free of carbides and retained austenite) with high and low carbon (carbon depleted) martensite.

\subsection{X-ray diffraction}

X-ray diffraction tests were carried out with the purpose of measuring the fractions of retained austenite in the samples. The proportion between retained austenite and bainitic ferrite were calculated through the refinement using Rietveld method by means of the software TOPAS ACADEMIC 4.1.

The amount of carbon dissolved in austenite was obtained using the method developed by Dyson \& Holmes ${ }^{13}$,

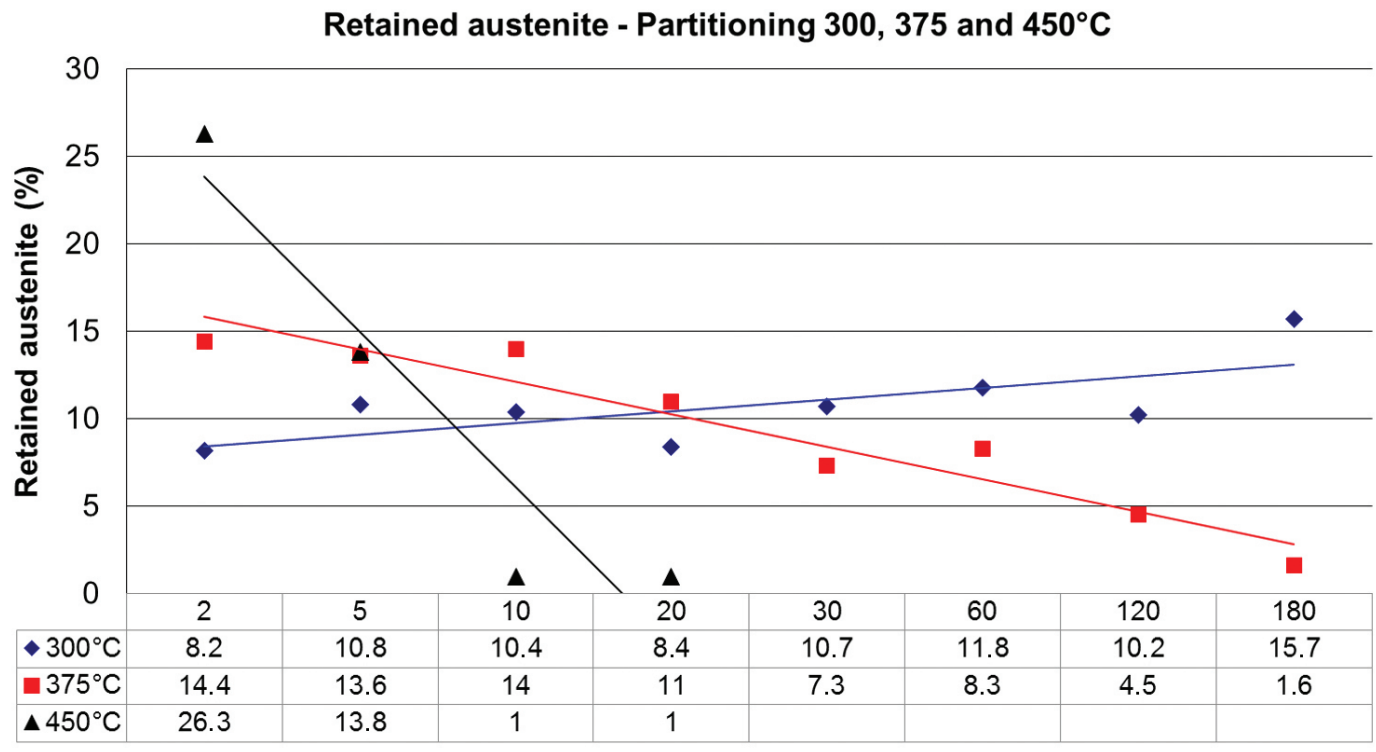

Partitioning Time (minutes)

Figure 2. Retained austenite fractions obtained in all partitioning conditions. 

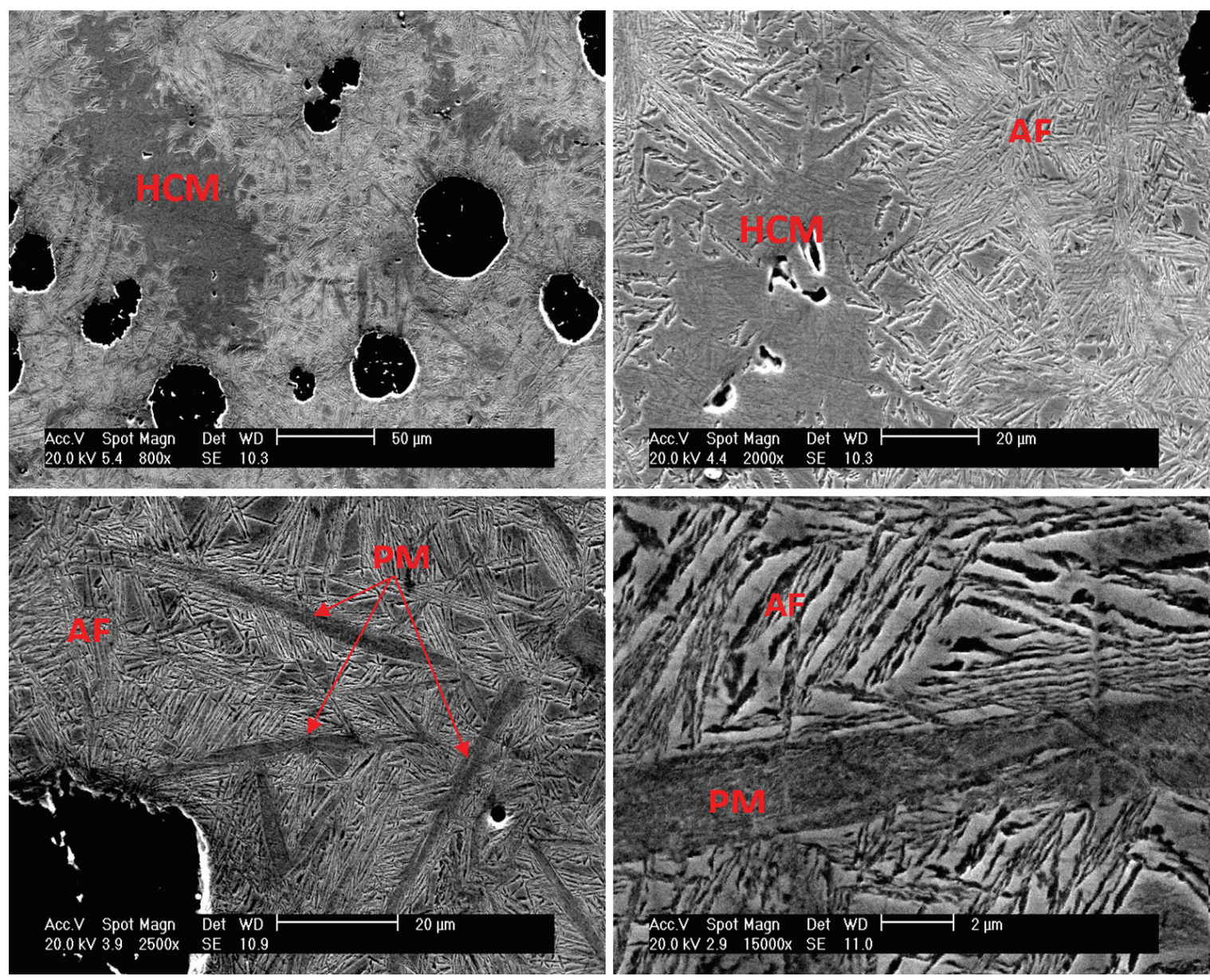

Figure 3. Samples partitioned at $300{ }^{\circ} \mathrm{C}$ during 5 minutes, showing high carbon martensitic areas (MAC) and ausferritic structure (AF) as well depleted carbon martensitic areas formed during quenching (MP) and acicular retained austenite (ARL) and bainitic ferrite (FB).

which considers the volumetric changes of crystalline structure with the percentage of alloying elements in solid solution, using the change of lattice parameters, making use of an empirical equation (Equation 3). Figures 2 and 4 present the volumetric fraction of retained austenite and the carbon content dissolved on austenite for all heat treatment conditions.

$\mathrm{a}_{\mathrm{cfc}}=3,5780+0,033 \mathrm{x} \% \mathrm{C}+0,00095 \mathrm{x} \% \mathrm{Mn}+$

$0,002 \mathrm{x} \% \mathrm{Ni}+0,0006 \mathrm{x} \% \mathrm{Cr}+0,0031 \mathrm{x} \% \mathrm{Mo}+0,0018 \mathrm{x} \% \mathrm{~V}$

The charts in Figures 2 and 4 show that it is possible to obtain sizeable fractions of retained austenite with considerable carbon content dissolved on austenite, depending on the partitioning conditions. The kinetics of transformation during the partitioning step shows strong dependence with the temperature. In general, the kinetics is accelerated by higher partitioning temperatures. In the samples partitioned at $300^{\circ} \mathrm{C}$, the retained austenite tends to increase during the 180 minutes of partitioning cycle, whereas the samples partitioned at $450{ }^{\circ} \mathrm{C}$ show the retained austenite peak in the first minutes of the partitioning cycle followed by fast subsequent decreasing contents. The graph of retained austenite and carbon content in solid solution shows that the higher contents were obtained faster when higher partitioning temperatures were used. In all conditions, the carbon content increases during the first minutes of heat treatment. After certain time, it is noticed that the carbon content dissolved on austenite decreases. This behavior is evidence that after certain time intervals, the austenite decomposes into other types of products, probably carbides of the second stage of bainitic reaction, the same phenomenon that occurs in ductile cast iron subjected to long austempering times.

\subsection{Impact energy}

The impact tests were performed to provide an estimate of the toughness of this new class of material. The data presented in Figure 5 show that the quenching and partitioning cycle is viable to obtain a class of cast irons with good values of impact energy, comparable to some classes of austempered ductile iron. This behavior is explained by the presence of retained austenite already confirmed by x-ray diffraction, which will improve the fracture toughness of material. The higher results of impact energy were $66.6 \mathrm{~J}$ on samples partitioned at $300{ }^{\circ} \mathrm{C}$ after 60 minutes; $81.4 \mathrm{~J}$ on samples partitioned at $375^{\circ} \mathrm{C}$ after 20 


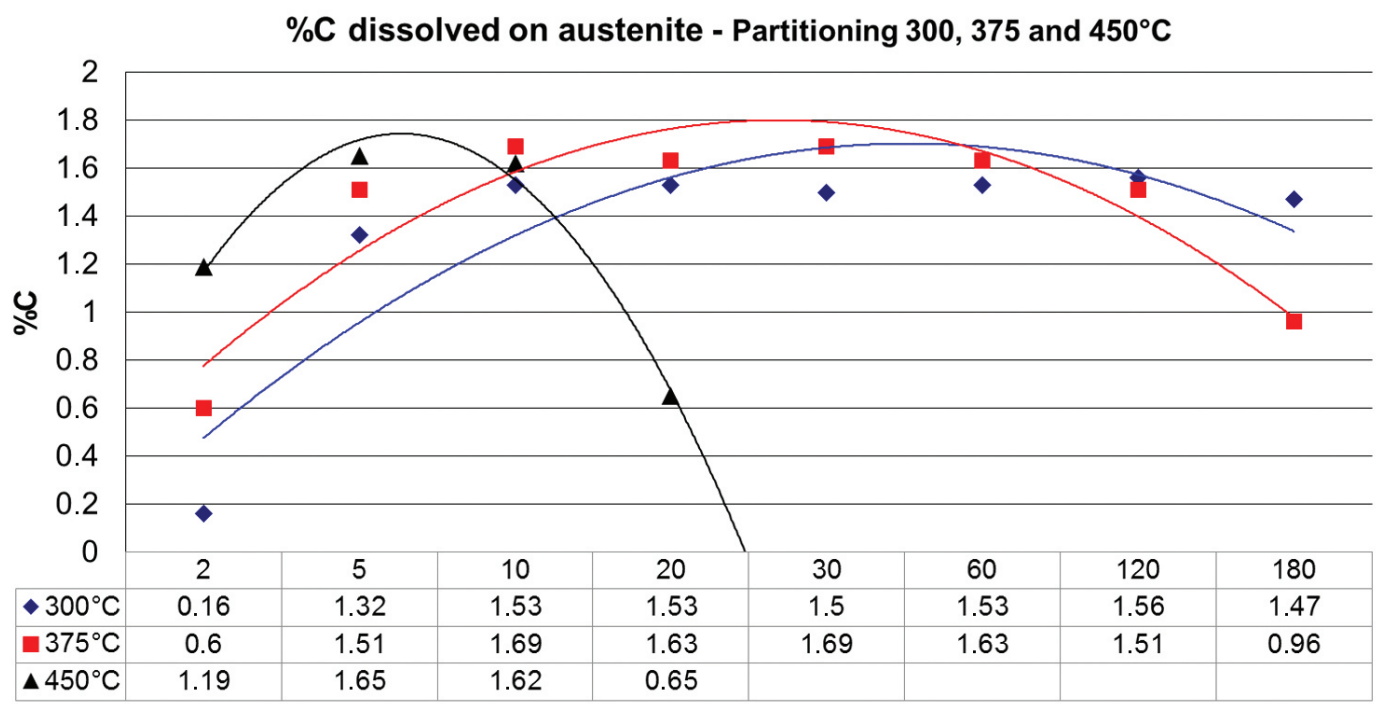

Partitioning Time (minutes)

Figure 4. Carbon content in solid solution in retained austenite obtained in all partitioning conditions.

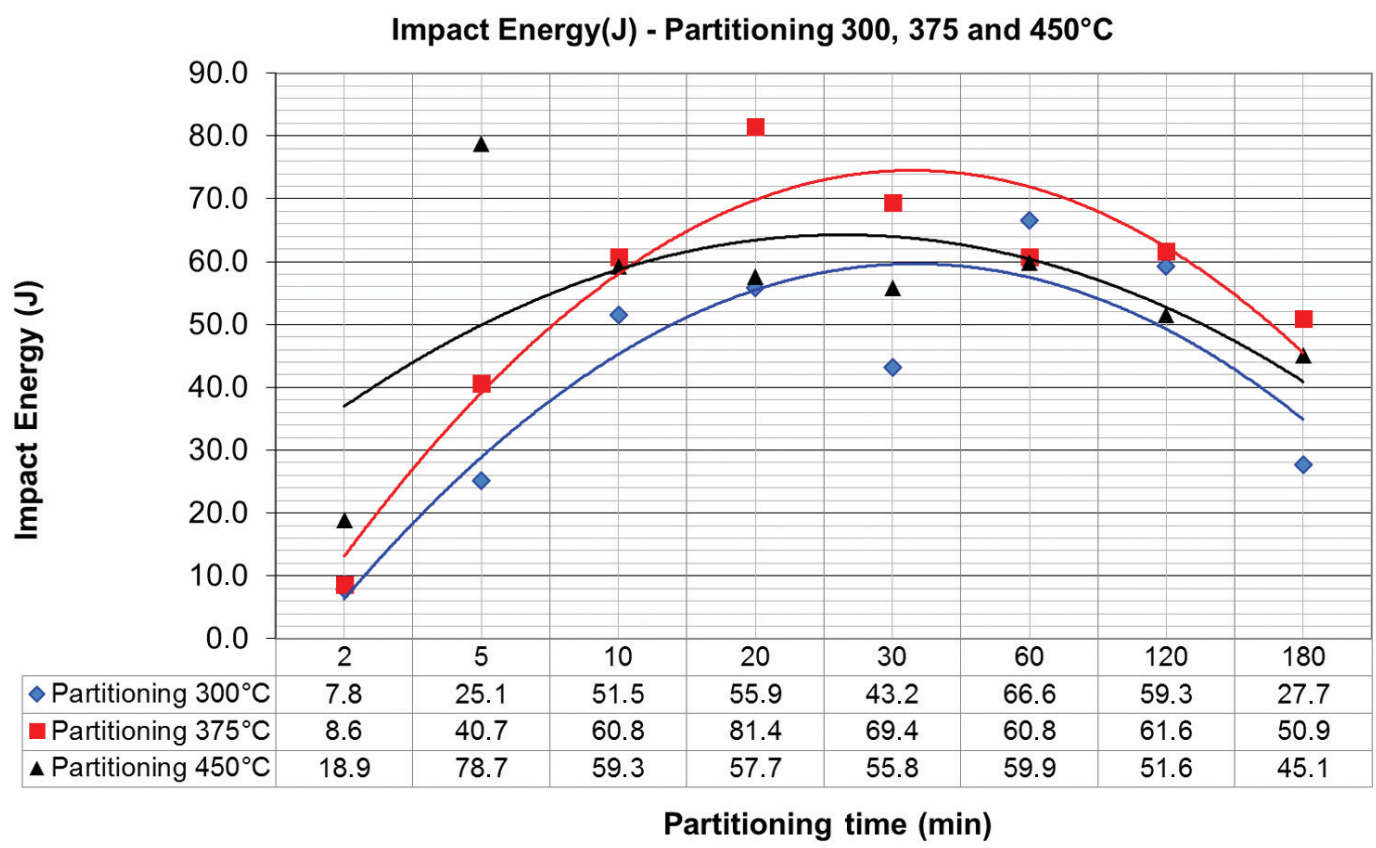

Figure 5. Impact energy $(\mathrm{J})$ for all heat treatment conditions.

minutes and $71.8 \mathrm{~J}$ on samples partitioned at $450{ }^{\circ} \mathrm{C}$ after 5 minutes. In all conditions it is noted the presence of a process window characterized by the increasing values of impact energy after the first minutes of partitioning cycle, which decrease after certain time intervals. For each heat treatment temperature used in this study there is a time interval that produces optimized properties. If the heat treatment time is longer or shorter than the process window, the mechanical properties will decrease.

\subsection{Tensile strength tests}

Analyzing Figure 6 it is observed that both the ultimate tensile strength and yield strength shows trend for increasing during the first 60 minutes of partitioning heat treatment, but decreasing for longer times. With the exception of the samples partitioned at $375^{\circ} \mathrm{C}$ the elongation tends to increase with time. For all tested conditions, the higher values of tensile/yield strength was observed after 60 minutes of partitioning. The partitioning temperature that produced the higher values of ultimate tensile/yield 


\section{Tensile Tests - Partitioning $300^{\circ} \mathrm{C}, 375^{\circ} \mathrm{C}$ and $450^{\circ} \mathrm{C}$}

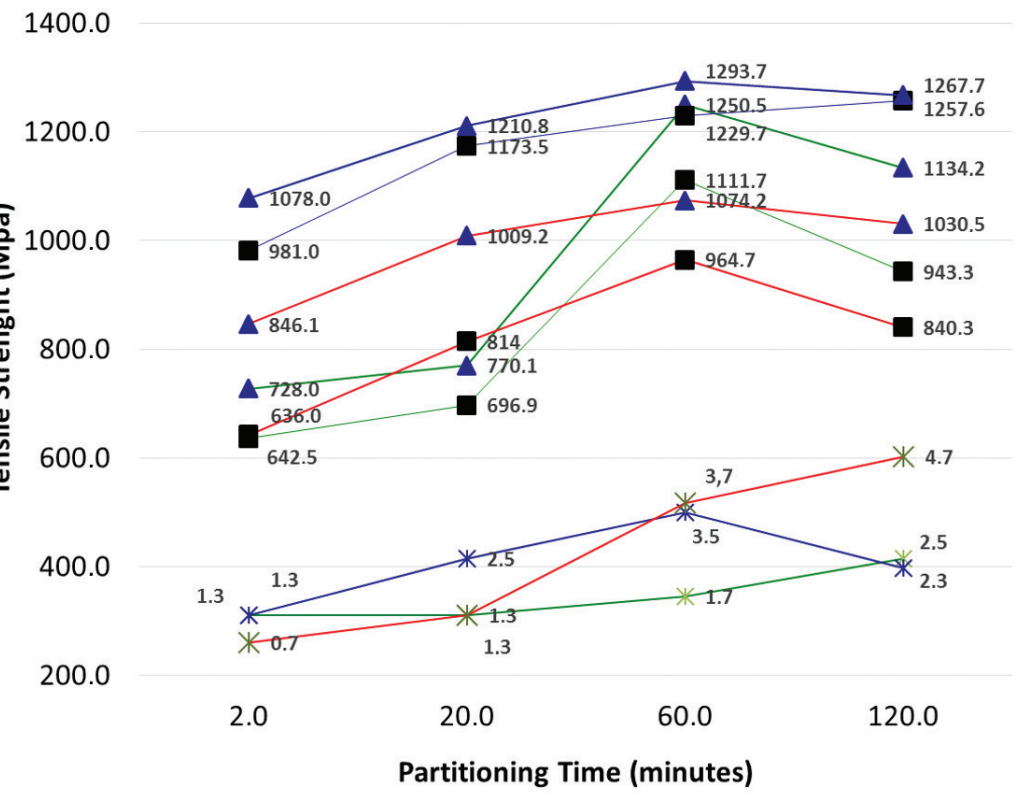

10

8

6

4

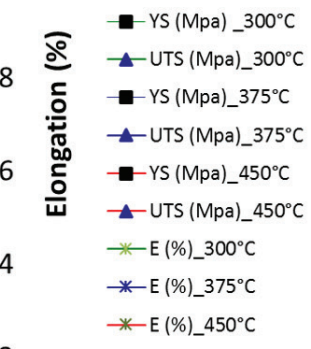

Figure 6. Tensile properties for all conditions tested.

and strength was $375^{\circ} \mathrm{C}$ after 60 minutes. In general, the partitioning cycle in this temperature was able to reach higher tensile strength. The best elongation result was achieved for the sample partitioned at $450{ }^{\circ} \mathrm{C}$.

Comparing results of tensile strength for all different heat treatment conditions tested, it is noticed that in general, the lower partitioning temperatures resulted in higher tensile/yield strength at the same time that higher temperatures resulted in higher elongation. The same behavior can be observed for austempered ductile irons. This phenomenon can be explained by the refinement of the structure obtained in lower temperatures, characterized by the decreasing size of the acicular ferrite, which is formed during isothermal treatment. This size reduction will hinder the dislocations movement. Another effect of lower austempering temperatures will be the decreasing of volumetric fraction of retained austenite present on ausferrite. On the other hand, the higher temperatures will produce lower volume fractions of acicular ferrite and increase the volumetric fraction of retained austenite, allowing higher elongation values.

\section{Discussion}

The concept of process window is widely used for the austempered ductile irons, and consists in the time intervals where it is possible to obtain optimal mechanical properties for each austempering temperature ${ }^{9}$. If the annealing time at the austempering temperature is too short, it is possible that certain portion of austenite will not be enough enriched by carbon to be able for reaching thermal stability and will transform to fresh martensite during cooling to room temperature, decreasing the material toughness. Thus, the elongation and impact energy decrease. On the other hand, if the annealing time is too high, the second stage of bainitic reaction will be reached, where the austenite, supersaturated in carbon, will decompose in carbides. This phenomenon will also decrease the toughness of material. In this way, for each austempering temperature used in heat treatment, there is a time interval where the material presents optimal properties. In general, higher austempering temperatures will produce more tight process windows, because the transformations during heat treatment will be accelerated ${ }^{9}$.

The observed behavior for all mechanical properties observed in this study suggests that it is possible to apply the concept of process window to ductile irons heat treated by quenching and partitioning process and it is possible to optimize mechanical properties by means of the correct selection of time interval of each partitioning temperature. The formation of martensite from the unstable austenite and the nucleation of carbides from the second stage of the bainitic transformation are the two most important embrittlement mechanisms of the ductile cast iron submitted to austempering. Similarly, it is possible to consider the presence of at least these two embrittlement mechanisms in quenched and partitioned ductile cast iron.

As discussed earlier, the segregation of chemical elements will change the local kinetics of transformation especially at intercellular areas, richer in elements such as manganese and molybdenum, which segregate to the last solidifying region. In the specific case of the alloy used in this study, the segregation of manganese to the intercellular area will benefit the formation of martensite during the final cooling, due to two main effects: i) the Ms temperature of the intercellular areas is reduced below the quenching temperature, avoiding the formation of martensite during the first step of heat treatment and ii) the formation of ausferrite in the intercellular areas will be difficult, producing large 


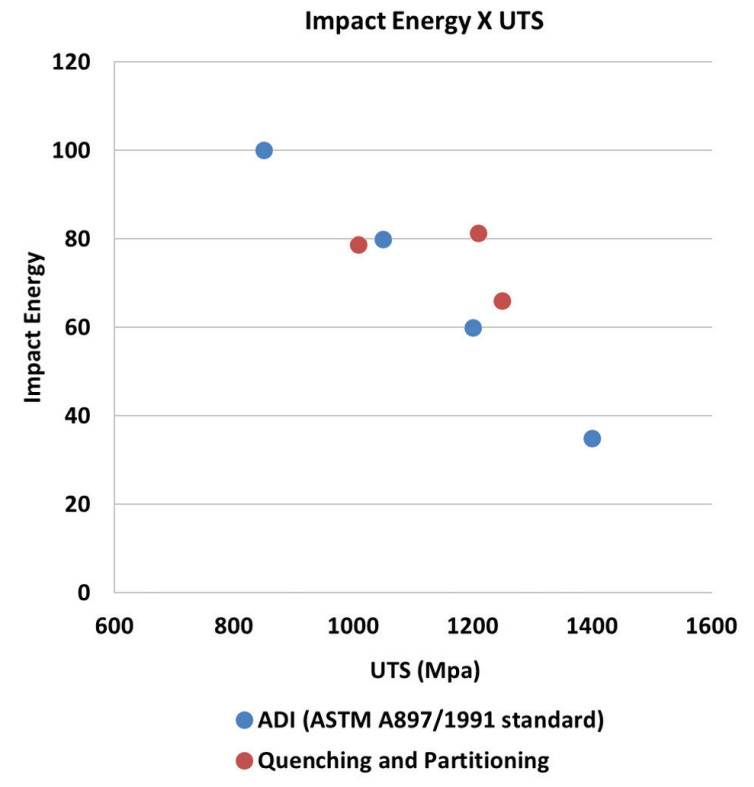

Figure 7. Mechanical properties map comparing ADI with quenching and partitioning ductile cast iron.

areas of cell boundary containing non-stabilized austenite, which transforms into martensite during the final cooling. Thus, high manganese contents shorten the process window, making less probable the stabilization of the intercellular austenite for smaller partitioning times. This effect can be minimized reducing the manganese content of the base alloy. Application of quenching and partitioning to thicker parts will require the use of alloying elements (Mo, Mn) in order to increase hardenability and therewith the effect of segregation of these elements tends to increase. In addition to their effects on kinetic of isothermal transformations, both manganese and molybdenum tend to form eutectic carbides at the end of the solidification, which are difficult to dissolving during austenitization step. These carbides will act as nucleation sites for cracks, affecting the mechanical properties in a deleterious way. Another option is the use of additions of nickel and copper, as these alloying elements do not segregate in intercellular areas. Another way for minimizing the segregation effect is increasing the amount of eutectic cells through inoculation. An effective inoculation can significantly increase the number of eutectic cells in the ductile cast irons and consequently improve the distribution of segregation on the microstructure 9 .

of view, presenting competitive potential in comparison with the austempered ductile irons for applications where this material has already been consolidated.

\section{References}

1. Speer JG, Assunção FCR, Matlock DK and Edmonds DV. The "quenching and partitioning" process: background and recent
Precipitation of carbides can occur due to the use of excessive times or too high temperatures during isothermal treatment. The experimental data for volume fraction of retained austenite and also carbon content in the austenite indicated that higher partitioning temperatures will accelerate the kinetics of reaction. This leads to higher percentages of retained austenite and carbon content in solution after shorter times. This is an evidence that higher temperatures accelerate the increase of carbon content in the austenite and its decomposition in other products such as ausferrite or carbides from second stage of bainitic reaction, the last one with embrittlement effect. In this way, the correct selection of partitioning temperature is the key to obtain the best combination of mechanical properties. The silicon content has an important influence avoiding the carbide formation in austempered ductile irons. Thus the correct selection of the silicon content added to the base alloy is an important way for the optimization of the process window and, thereafter, the mechanical properties.

Comparing the mechanical properties of the samples used in this study with the mechanical properties of austempered ductile iron, the quenching and partitioning heat treatment originates ductile cast irons with a level of properties as good as the austempered ductile irons, as can be seen on Figure 7.

\section{Conclusions}

The quenching and partition is a viable route to obtain ductile irons with considerable volumetric fractions of retained austenite, such as steels.

The microstructural analysis shown that the resulting microstructure is composed by a mixture of partitioned martensite (low carbon) plus high carbon martensite plus ausferrite (bainitic ferrite free of carbides plus retained austenite).

In intercellular areas, there is predominance of high carbon martensite formed from unstable austenite. In other areas, ausferrite formed in the partitioning cycle will predominate. These differences are due to the gradient of chemical composition between these areas.

The process window concept can be used to ductile cast irons heat treated by quenching and partitioning cycle.

The two main embrittlement mechanisms that will define the process window are the martensite formation from the areas of unstable austenite and the carbides precipitation from the second stage of bainitic reaction.

The combination of properties obtained with quenching and partition is very interesting from the engineering point

progress. Materials Research. 2005; 8(4):417-423. http:// dx.doi.org/10.1590/S1516-14392005000400010.

2. Thomas GA, Speer JG and Matlock DK. Considerations in the application of the "quenching and partitioning" concept to hotrolled AHSS production. AIST Transactions. 2008; 5:209-217.

3. De Moor E, Lacroix S, Clarke AJ, Penning J and Speer JG. Effect of retained austenite stabilized via quench and partitioning on the strain hardening of martensitic steels. Metallurgical and Materials Transactions. A: Physical 
Metallurgy and Materials Science. 2008; 39(11):2586-2595. http://dx.doi.org/10.1007/s11661-008-9609-z.

4. Clarke AJ, Speer JG, Miller MK, Hackenberg RE, Edmonds DV, Matlock DK, et al. Carbon partitioning to austenite from martensite or bainite during the quench and partition (Q\&P) process: a critical assessment. Acta Materialia. 2008; 56(1):1622. http://dx.doi.org/10.1016/j.actamat.2007.08.051.

5. Trudel A and Gagné M. Effect of composition and heat treatment parameters on the characteristics of austempered ductile irons. Canadian Metallurgical Quarterly. 1997; 36(5):289-298. http://dx.doi.org/10.1179/cmq.1997.36.5.289.

6. Edmonds DV and Speer JG. Martensitic steels with carbide free microstructures containing retained austenite. Materials Science and Technology. 2010; 26(4):386-391. http://dx.doi. org/10.1179/026708309X12512744154162.

7. Zhong N, Wang XD, Wang L and Rong YH. Enhancement of the mechanical properties of a Nb-microalloyed advanced high-strength steel treated by quenching-partitioningtempering process. Materials Science and Engineering. 2009; 506(1-2):111-116. http://dx.doi.org/10.1016/j. msea.2008.11.014.
8. Matlock DK and Speer JG. Processing opportunities for new advanced high-strength sheet steels. Materials and Manufacturing Processes. 2010; 25(1-3):7-13. http://dx.doi. org/10.1080/10426910903158272.

9. Guesser WL. Propriedades mecânicas dos ferros fundidos. São Paulo: Blucher; 2009. p. 23.

10. Liu C, Zhao Z, Northwood DO and Liu Y. A new empirical formula for the calculation of MS temperatures in pure iron and super-low carbon alloy steels. Journal of Materials Processing Technology. 2001; 113(1-3):556-562. http://dx.doi. org/10.1016/S0924-0136(01)00625-2.

11. Koistinen DP and Marburger RE. A general equation prescribing the extent of the austenite-martensite transformation in pure ironcarbon alloys and plain carbon steels. Acta Metallurgica. 1959; 7(1):59-60. http://dx.doi.org/10.1016/0001-6160(59)90170-1.

12. Speer JG, Matlock DK, Cooman BC and Schroth JG. Carbon partitioning into austenite after martensite transformation. Acta Materialia. 2003; 51(9):2611-2622. http://dx.doi.org/10.1016/ S1359-6454(03)00059-4.

13. Dyson, DJ, Holmes, JB. Effect of alloying additions on lattice parameter of austenite. Journal of Iron and Steel Institute. 1970; 208:469-470. 